\title{
階層行動アーキテクチャ （適応と学習によるシステムの最適化）
}

\author{
柴 田崇 徳* 福 田敏 男**
}

\section{1.はじめに}

様々な環境で, 目的に応じて複雑な行動, 作業を行 う能力を持つ知的なロボットが広く求められている. そのため, ロボットの知的制御は, 人間の思考, 感 覚, 運動を模倣し, 同様の制御アーキテクチャを与え ることによって達成されると考えられ研究されてき た ${ }^{1) \sim 12)}$. 個別には，作業に関する知識，作業の計 画, センサ情報の理解, 運動システムのスキルや制 御，さらに，環境モデルや操作者である人間との情報 交換のためのマン・マシンインタフェースの研究等が ある ${ }^{13) \sim 16)}$. 知的制御のためには，これらを統一的に 扱うことが必要である. 本稿では, 知的制御方法とし て階層的な制御アーキテクチャについて述べる。

ロボットが行動する実際の環境は不確かさを含むた め, 人間が与える知識や行動規範には限界がある ${ }^{177}$.

したがって制御のアーキテクチャとあらかじめ与えら れた知識を先天的な知能とすると, ロボット自身が 様々な環境での行動から経験的に後天的知能を獲得す る能力が必要である。このような知識獲得のために は，トップダウン的な人間の教示と，ボトムアップ的 なロボットの自律的行動による適応と学習が人工生命 (Artificial Life) とも言える知的ロボットに必要であ $る^{64), 65), 71), 72)}$.

ニューラルネットワーク (Neural Network : NN), ファジィ, 遺伝アルゴリズム (Genetic Algorithm : GA）は，後天的知能のために有効な技術である。こ れらの技術は特徵に応じて適用するレベルが異なるが, 得意とする所へ個別に適用するだけでなく, 融合化, 統合化によりそれぞれの短所を相補い長所を生かし,

原稿受付 1993 年 9 月 7 日

Hierarchical Control Architecture for Intelligent Behavior -Sophistication of System by Adaptation and Learning *機械技術研究所

**名古屋大学工学部
新たに，より高度な情報処理を行うための研究がな されている，本稿では，知的ロボットのための階層的 な制御アーキテクチャの構成, 特徵などを概説する.

\section{2. 階層制御アーキテクチャ}

ロボットの知的制御は，始めは人工知能 (Artificial Intelligence: AI), 特にエキスパートシステムの応 用として研究されるようになった。 そこでは, 記号化 された情報の推論，知識獲得とその利用等，主に論理 情報処理が研究された。しかし，ロボットに必要な知 能と知識は，ロボットが働く現実の世界の物理的特 性, 幾何学的特徵を含まなければならない. 例えば, 組立て作業時の作業計画や運動制御に関する知能や部 品の寸法, 形状, 重量, 精度, つかみ位置等に関する 知識である。これらの知識を用いて知的制御を行うた めに，制御アーキテクチャの中に，記号を扱うレベル と数值を扱うレベルを含むシステムを構築する必要が ある.これらのシステムを統合し知的制御を行うため に，人間を規範とした階層型の制御アーキテクチャが 提案されてきた。

人間を規範とする上で, Rasmussenは人間の行動 を, 知識に基づくレベル，ルールに基づくレベル，そ してスキルに基づくレベルの 3 つの階層構造にカテゴ リを分けた（図 1） ${ }^{3)}$.そして，スキルに基づくレベル はシグナル，ルールに基づくレベルはサイン，知識に 基づくレベルはシンボルを扱うことを述べている．こ のモデルは低レベルの運動の制御までは含まれていな いが，ロボットの知的制御のための階層的な制御構造 を与える指針と言える。

人工知能と学習制御を階層的に統合することを $\mathrm{Fu}$ が提唱し，Saridisは，ロボットの知的制御のために 階層的な知的制御として, 組織レベル, 調整レベル, ハードウエア制御レベルの 3 つに分けて提案した（図 2) ${ }^{1) 33,44}$. 組織レベルは外部 (人間) からの入力コマン ドを受け付け解釈し，またシステムのフィードバック 


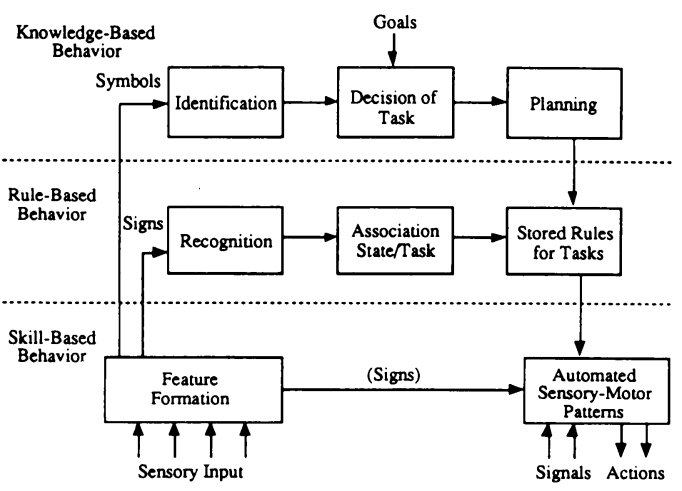

図 1 Rasmussenの階層モデル

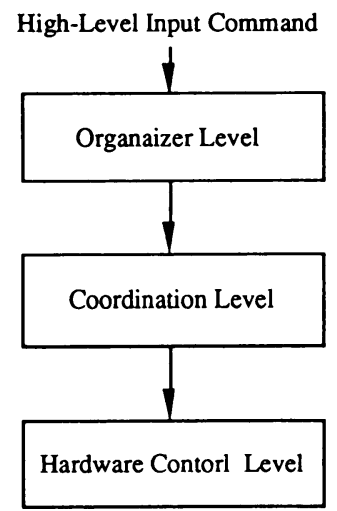

図2 Saridis の階層制御のモデル

情報を解釈する，そして，タスクを定義し，プランニ ングによって実行順にサブタスクに割り振りする．調 整レベルは，上位の組織レベルからの指示を受け，ま た実行されているそれぞれのサブタスクのプロセスか らのフィードバック情報を受ける，そして，最下層で のタスクの実行を調整する．その最下層のハードウエ ア制御レベルは，プロセスの数学モデルとともに，調 整レベルによって定義されるサブタスクと評価関数に 基づいて作業を実行するものである。

一方, Albus は, 人間の脳と体性感覚情報, 運動機 能との関係を述べ，小脳のモデルである $\mathrm{CMAC}$ を提 案し，その学習能力を生かし，マニピュレータの制御 方法を提案した ${ }^{6), 25)}$. さらに, 人間の思考, 感覚, 運 動の階層性からロボットの階層制御を提案し，これを ベースとして, Real-Time Control System (RCS) としてNASREMを提案した ${ }^{61,69)}$. 図3にその概念図 を示す. Meystelも，このNASREMのアーキテク チャを用いてロボットの知的制御のためにMulti-

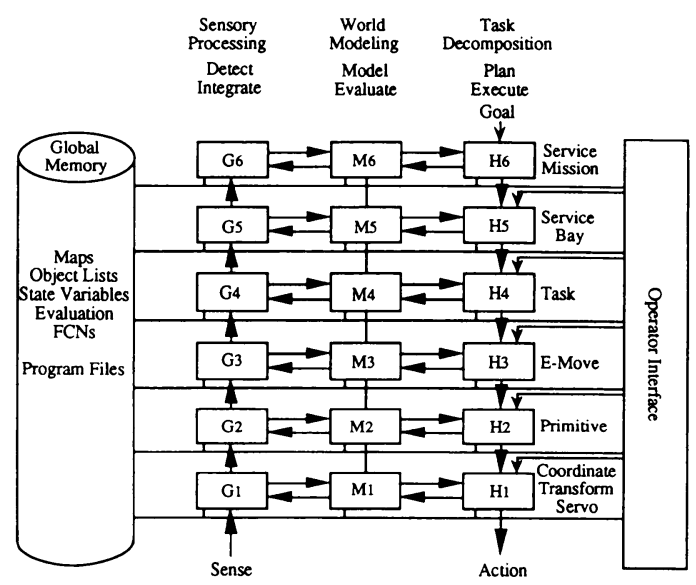

図 3 NASREM のアーキテクチャ

resolutional Control Architecture を提案してい る70). NASREM は大きく分けてタスク分解，ワール ドモデリング，そしてセンサプロセッシングの 3 つの モジュールから成り立っている，それぞれのモジュー ルは階層的なネットワーク構造を持つ.グローバルメ モリはデータベースであり, 外界の状態を推定したモ デルを蓄えておくことができ，各モジュールを助ける 役割を果たす。タスク分解モジュールは，上位レベル のタスクの目標を下位レベルでの行動に時間的にも空 間的にも分割するよう計画する．各階層のそれぞれの レベルでタスク分割モジュールは, タスク割当て, 計 画，実行を行う。ワールドモデリングモジュールは， 内界，外界の状態をモデル化し評価を行う。ワールド モデルは過去の推移, 現在の状態, 将来起こり得るこ とが予想される状態のモデルをそれぞれ持つ、ワール ドモデリングのモジュールとともに, 状態変数や, マ ップ，対象物や事象のリストや属性などがグローバル メモリの知識ベースに蓄えられている。ワールドモデ ルは，センサシステムの情報に基づくグローバルメモ リ知識ベースを維持し，タスクや外界の状態に応じた センサ入力の予測值を対応するセンサモジュールに与 え, 対応する夕スク分解モジュールの実行システムか らの外界情報に関する質問に答え，またタスク分解モ ジュールの計画システムによる仮定的な質問に対して も返答する，センサプロセッシングモジュールはパ夕 ーンを認識し，事象を検出し，時間や空間を超えてセ ンサ情報のフィルタリングや, 統合を行う。センサプ ロセッシングモジュールは, ワールドモデルの予測 と, 観測された結果を比較し, 相関や違いを計算す る。新しく検出された事象や対象物や関係をワールド 
モデリングモジュールを用いてグローバルメモリデー タベースに記憶する。一方存在しない事象や対象物や 関係は消去される。それぞれのレベルにはオペレータ のインタフェースを備える。したがって，ロボットは 必ずしも自律型である必要はなく，テレオペレーショ ンなどの機能を有することができる．時間の概念で は，1つの夕スクの長さが異なり，下位になるほど短 く，上位レベルが計画して下位レベルが実行する．フ イードバック情報で，下位レベルの失敗を検出したと き，すぐにサブタスクを再計画する.

NASREM の機能的な構成は非常に優れていると考 えられるが，実際には下位のサーボレベルとプリミテ イブレベルだけでシステムが構成され，実験によって 有効性が示されている，更に上位を構成するために は，具体的な方法を検討する必要がある．NASREM のシステム構成は人間が設計し，その知識を人間が与 えるトップダウン的なシステムであると言える。上位 レベルでの外界モデルの表現方法，各レベルをリンク するためのインタフェース，知識の獲得方法が問題で ある.

Brooks は, 自律ロボットが行動する実世界の環境 を記号化することが困難であること，AI の問題解决 能力の不十分さ, 記号的に計画された解に基づく行動 への低い信頼性を問題であるとし，昆虫などの自律シ ステムを模倣したサブサンプションアーキテクチャを 提案した ${ }^{17)}$. 従来の $\mathrm{AI}$ 的手法とはまったく異なる が，階層的なモジュールの構成で，上位レベルが下位 レベルを包括し，優先順位を持っている（図 4).その 構造は最下層から順に上位レベルにボトムアップで構 成される.しかし, 学習能力はなく固定的であり, 上 位レベルを構成しようとすると高度な設計技術を必要 とする，また内界，外界のモデルがない場合，推論や コミュニケーションを必要とするような複雑な作業を 行うことはできない. したがって, 一台のロボットが 自律的に行動することができても, 複数台で分散的に 協調動作を行うような作業を行うことが不可能であ る.それでも，従来の AI 的手法に対するインパクト は大きく，多くの研究者が応用している.

近年は，ロボットマニピュレータによって組立てな どの高度な作業を行わせることを目的とする，階層的 な制御方法の研究が多い. 産業用ロボットにおいて は, 動作教示方式を基礎としている. しかし知能ロボ ットは，教示なしに環境や作業の変化に適応すること が望まれる，そこで，そのような環境モデルの変化や 誤差に対しても，器用に動作し作業を達成する能力,

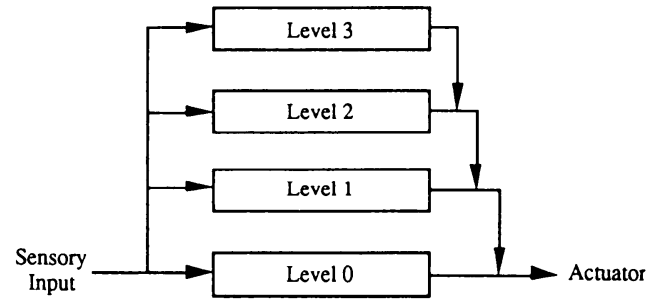

図4サブサンプションアーキテクチャ

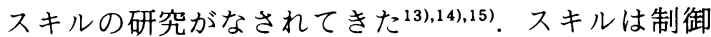
の階層構造の中位にあり，上位と下位を円滑に結ぶ役 割をする，特定の作業だけでなく各種の作業に関する スキルを蓄積することが望まれる。

1 台のロボットで複雑な作業を行うと階層アーキテ クチャ内で情報の流れが多く，かつ複雑になるため情 報伝達が遅れてしまう。したがって，1台のロボット でなく複数台のロボットによって分散的にタスクを実 行することが望まれる。このとき，完全な自律分散型 システムであると作業能率を最適にすることは保証さ れない. したがって, 階層的にリーダーが存在し, あ る程度集中的にタスクの分割を行い，そのサブタスク を協調しながら複数のロボットで分散的に行うミック ス型のシステム形態が望ましい。しかも，その形態は タスクに依存して自己組織的に決定されることが望ま しい.このような目的のために，エントロピーを用い てリーダーの数やシステムの効率を評価する方法が研 究されている63).

従来の研究では，階層的な制御アーキテクチャを構 成することによって，知的制御を行えるとして様々な アーキテクチャが議論されてきた，そこでは，複雑な タスクを扱う場合には，トップダウン的にシステム設 計者の能力や，作業に依存した知識を与え，主に特定 の既知の環境を扱うことによって，知的な行動をロボ ットがするようになされてきた。しかし，知識の限界 や環境の不確かさを解決するためには，適応と学習の 機能をシステムが持つことが必要である。 また階層的 な制御アーキテクチャを構成する上で，数值を扱う現 実の世界と論理的な記号の世界との接点をどのように 扱うかが重要である.つまり環境のモデル化方法, セ ンサからの信号を処理し記号に変換する方法，作業に 関する知識の表現方法や学習方法等が重要である。こ れらの機能は後天的な知能として,ソフトウエアに依 存する度合が高い，次章以降にこれらを達成するため に有効な方法として NN・ファジィ・GA を用いる方法 を示す。 


\section{3. ニューロ, ファジィ, 遺伝アルゴリズム の概要}

ロボットの知的制御のため, AI とともに NN・ファ ジィ・GA を階層的制御構造のそれぞれのレベルで, あるいは各レベルを結ぶように，統合，融合化しなが ら適用する研究がなされている(図 5)191 62),67),68). NN は神経回路網をシンプルにモデル化したものであり， 並列処理, 学習機能, 自己組織化能力など多くの優れ た特徴を有している ${ }^{18), 19)}$ 。そして，連想記憶，パ夕 ーン認識, 総合的判断などの情報処理を得意としてい る.ファジィ理論は, 曖昧性を取り扱うシステムとし て広く使用されている．「やや良い」「やや悪い」とい った主観的評価を，メンバーシップ関数と称する特性 関数で体系化したものである. 従来の If.. , then.. ル ールはディジタル的評価を下すものであったのに対 し, ファジィ理論はその中間值をとり得るものであ る ${ }^{44), 45)}$. GA は遗伝子情報を用いた生物の進化の過程 を模倣した最適化法の 1 つである55). アルゴリズムは 世代と呼ばれるステップで進む. 最適化問題では，解 を個体で表現し, 評価関数を定義する. 個体群の中 で, 評価值の高い個体を次の世代に生き残るように淘 汰し, 交叉や突然変異の遺伝操作により増殖を行い, その繰り返しによって進化させる. 個体は, 関数空間 のサンプル点と見ることができ，多峯性の解空間に対 して, 個体群によるグローバルな多点探索を勾配情報 を用いずに行えることが特徵と言える.

階層的な制御アーキテクチャは, 数值信号と記号を 扱う必要があり, その信号変換のために NN, ファジ イを用い, AI で論理的推論を行うための前処理や後 処理に用いることができる. これらの信号変換の仕方

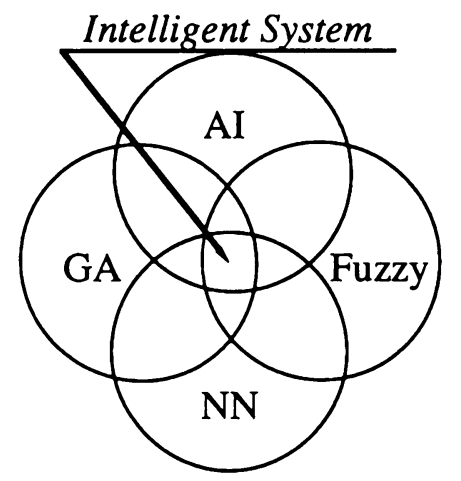

図 5 インテリジェントシステムのための $\mathrm{AI}$, ニュ 一ロ, ファジィ, GA の統合と融合
や違いについては，参考文献を参照されたい71)，GA は，試行錯誤的な探索を行うので，知識獲得の上でオ ペレータである人間が, 予想しない結果を発現するこ とが期待できる. 個体を直接的に記号表現したり, $\mathrm{NN}$ ，ファジィによって間接的に数值を扱うことも可 能である。これら NN，ファジィ，GA を用いた階層 的知的制御について次章に述べる.

\section{4. 階層的知的制御}

人間に近い動作ができる知的ロボットには, センサ システム, アクチュエータの制御，環境に適合した制 御戦略のための論理判断が必要である.これらの要素 を統合して制御系を構成するための, 階層的知的制御 システムについて述べる(0),11),12),47),72).

システムは, 学習レベル, スキルレベル, 適応レベ ルの 3 つの制御のレベルから構成されている (図6). 学習レベルは認識と計画によって制御戦略を生成す る. 認識レベルは, If.., then.. ルール, NN, ファジ イを様々なセンサモジュールで数值を記号化するため のセンサシステムとのインタフェースとして用い, 戦 略決定のための决定木の節として用いる. 知識に基づ き必要なセンシングを能動的に行い, 細かな認識を行 う. 複数のセンサ情報に基づく推論によりセンサフュ ージョンやメ夕知識を形成する. NNを用いてセンサ 情報を分類する場合，新たな知識として未学習のパ夕 ーンを追加する必要があることが多い. この場合, 構 造化した NN が有効であり, システムの可変性を高 める ${ }^{43)}$. 認識後, 計画レベルは, タスク, 軌道等をデ ータベースにあるモデルや知識を用いて計画する. 制 御戦略決定後は，データベースから適応レベルに対し て，制御目標や制御ゲイン，コントローラにある NN に対する学習済み結合荷重等を与える。このように,

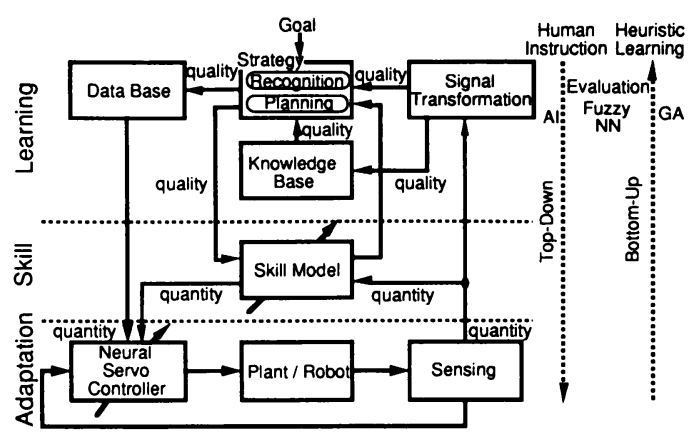

図6 ニューロ，ファジィ，GA を用いた階層的知的 制御システム 
学習レベルはフィードフォワード制御として，下位の レベルに環境特性に合わせた制御戦略を与え, 同時に 下位レベルの制御結果を評価する。評価には，人間オ ペレータとのインタフェースとしてファジィを用いる ことも有効である62).

スキルレベルは，環境変化に対し適応レベルの制御 の目標値を修正するだけでよい場合に，時間のかかる 論理的推論を行わずに作業のやり方を与える．人間の スキルをファジィで表現する方法や, 複数の既知デー 夕から学習するファジィ NNによる方法が有効であ る47). 獲得されたファジィ NNの内部ルールは人間 のスキルを表現し，メンバーシップ関数は記号情報と して上位レベルで用いる.

適応レベルは，制御ゲインを調節，あるいは補償す るものである。特に非線形なシステムやその補償は $\mathrm{NN}$ が得意である.ダイナミックな NN を用いたコ ントローラは, 非線形性が強く, 不確かさを含むダイ

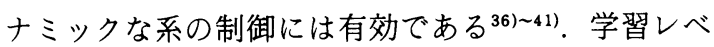
ルから与えられる制御戦略は, データベース上の記号 的な 1 点であるため, 大まかであり実際の環境特性と は若干異なっている可能性が高い.そのような記号か ら数値への変換によって生じる不確かさを $\mathrm{NN} に よ$ る適応によって補償する.

学習レベルにおける推論のための知識を獲得するた めの長時間の学習プロセスとして, まずボトムアップ 的に下位レベルにおいて, 試行錯誤によって環境に適 応する、その結果に対するトップダウン的な人間によ る教示や評価を用い, 学習レベルは知識を獲得, 更新 する、試行錯誤の振り方を決めるには GA が有効で ある.

階層的知的制御は, 複数ロボットシステムにおいて も有効である. 複数ロボット間で作業空間, 作業道具 等の資源を共有する場合, 競合により衝突やデッドロ ックが生じ得る.この競合の解消のため, 待ち動作等 を行うと作業効率が落ちる。資源を有効利用するた め, 全体で最適な計画を立てることが必要である.こ のような, 大規模な計画には複数ロボットシステムを 階層化し, 分散と集中をミックスし最適化を行うこと が有効である.このとき, 組合せの爆発などの問題が 生じるが, 最適化法の 1 つとして GA が有効であ

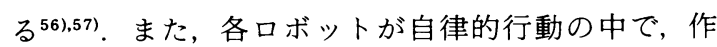
業の繰り返しからほかのロボットの動作を予測できる ように学習し, 協調的動作によりシステムの効率を上 げることもできる。このとき，学習によって獲得され た経験や環境を表現するには，ファジィや NNを用
いることが有効であり，そのような表現を用いながら 最適化を行うには，勾配情報を用いない GA が有効 である ${ }^{58)}$.

以上のように，階層的な制御アーキテクチャの中 で, AI, ファジィ, ニューロ, GA を統合, 融合する ことによって, 先天的知能を備え, 後天的にボトムア ップとトップダウンの統合によって学習する知的シス テムを構築することが可能である711,72).

\section{5. まと め}

人間の思考, 感覚, 運動を模倣し知的なシステムを 構築することを目的とした，階層的な制御アーキテク チャの研究の歴史は古く, 様々な手法が研究されてき ている.しかし，トップダウンに知識を与えるだけて は，真に知的なシステムを構築することができず，口 ボットの自律的な行動を基本としたボトムアップ的な 知識獲得行動, つまり適応と学習が重要である.その ような後天的知能のために， NN，ファジィ， GA は 非常に有効である，階層的な制御アーキテクチャに適 用することによって, 自律ロボット，自律分散システ ム, 自己組織化システム, そして進化型ロボットシス テム研究への発展が期待される.

\section{参 考 文 献}

1) K.S. Fu, "Learning Control System and Intelligent Control Systems: An Intersection of Artificial Intelligence and Automatic Control," IEEE Trans. on Automatic Control, Vol. AC-16-1, pp. 70-72 (1971)

2) A. Freedy et al., "A Computer-Based Learning System for Remote Manipulator Control," IEEE Trans. on Systems, Man, and Cybernetics, Vol. SMC-1-4, pp. 356363 (1971)

3) J. Rasmussen, "Skills, Rules, and Knowledges; Signals, Signs, and Symbols, and Other Distinctions in Human Performance Models," IEEE Trans. on SMC, Vol. 13, pp. 257-266 (1983)

4) G. N. Saridis, "Toward the Realization of Intelligent Controls," Proc. of the IEEE, Vol. 67-8, pp. 1115-1133 (1979)

5) G. Saridis, "Intelligent Robotic Control," IEEE Trans. on Automatic Control, Vol. 28-5, pp. 311-321 (1983)

6) J.S. Albus, "Brains, Behavior, and Robotics," McGraw-Hill (1981)

7）福田, “極限作業用知能ロボット”, マグロウヒル (1986)

8）白井, 井上, “知能ロボット研究の展望一モデルベースト・ ロボティクスー”, 日本ロボット学会誌, Vol. 5-6, pp. 462469 (1991)

9) 辻, “知的ロボティクスの幾つかの問題”, 日本ロボット学 会誌, Vol. 9-1, pp. 79-84 (1991)

10）柴田他, “神経回路モデルによるロボット・マニピュレータ の位置・古制御の研究(第 5 報)”, 機論, C 編, Vol. 57-540, pp. 2659-2666 (1991) 
11）柴田他, “神経回路モデルによるロボット・マニピュレータ の位置・力制御の研究(第 6 報)”，機論, C 編, Vol. 58-549, pp. 1442-1449 (1992)

12) T. Shibata and T. Fukuda, "Hierarchical Intelligent Control of Robotic Motion," IEEE Trans. on Neural Networks (1992) (to appear)

13）末広, 高瀬, “スキルに基づくマニピュレーションシステム, 日本ロボット学会誌, Vol. 8-5, pp. 551-562 (1990)

14）小菅,“テレロボティクスにおけるスキル獲得とその利用”, 第 8 回日本ロボット学会学術講演会, pp. 585-588 (1990)

15) S. Liu and H. Asada, "Transferring Manipulative Skills to Robotics : Representation and Acquisition of Tool Manipulative Skills Using a Process Dynamics Model," Trans. of the ASME, Journal of DSMC, Vol. 114, pp. 220-228 (1992)

16) B. J. McCarragher and H. Asada, "A Discrete Event Approach to the Control of Robotic Assembly Tasks," Proc. of IEEE Conf. on R\&A, Vol. 3, pp. 331-336 (1993)

17) R. A. Brooks, "A Robust Layered Control System for a Mobile Robot," IEEE J. Robotics and Automation, RA-2, pp. 14-23 (1986)

18) D. E. Rumelhart et al., "Parallel Distributed Processing," MIT Press (1987)

19) T. Fukuda and T. Shibata, "Theory and Applications for Neural Networks for Industrial Control Systems," IEEE Trans. on Industrial Electronics, Vol. 39-6, pp. 472-489 (1992)

20) P. J. Werbos, "Backpropagation Through Time: What It Dose and How to Do It," Proc. of the IEEE, Vol. 7810, pp. 1550-1560 (1990)

21）福田, “石上画像処理エキスパートシステムによるマイク ロキャリア上動物細胞の視賞認識・計測法 (第 4 報, GA によるニューラルネットワーク初期值探索問題)”, 機論, C 編, Vol. 59-561, pp. 1482-1488 (1993)

22）福田他, “遺伝アルゴリズムを用いたリカレントニューラ ルネットワークの学習”, 機論, C編, Vol. 59-564, pp. 22982304 (1993)

23）柴田他, “リカレントニューラルネットワークを用いたガ 夕の補償制御一遺伝アルゴリズムによる教師なし学習一”, SICE 93 講演会予稿集 (1993)

24) B. Widrow, "Generalization and information Storage in Network of Adaline "Neurons", In Self-Organizing Systems-1962," pp. 435-462, Spartan Books (1962)

25) J.S. Albus "A New Approach to Manipulator Control : The Cerebellar Model Articulation Controller (CMAC)," Journal of DSMC, pp. 220-227 (1975)

26) S. Grossberg and M. Kuperstein, "Neural Dynamics of Adaptive Sensory-motor Control, Pergamon Press (1989)

27）川人，“随意運動制御における適応と学習”, 日本ロボット 学会誌, Vol. 4-2, pp. 184-193 (1986)

28）㨶田他, “神経回路モデルによるロボットの力制御( 1 自由 度マニピュレータの制御)”、日本ロボット学会誌, Vol. 71, pp. 47-51 (1989)

29）福田他, “神経回路網によるロボット・マニピュレー夕の位 置・力制御の研究(第 1 報)”, 機論, C 編, Vol. 56-527, pp. 210-216 (1990)

30) P. J. Werbos, "A Menu of Designs for Reinforcement Learning Over Time," in W. T. Miller, R. S. Sutton, and
P. J. Werbos (Eds), Neural Networks for Control, pp. 67-95, MIT Press (1990)

31) K. S. Narendra and K. Parthasarathy, Identification and Control of Dynamical Systems Using Neural Networks," IEEE Trans. on Neural Networks, Vol. 14-27 (1990)

32）橋本他, “視覚情報によるマニピュレータの位置・姿勢制御 一ニューラルネットワークの利用一”, 日本ロボット学会 誌, Vol. 8-4, pp. 390-396 (1990)

33) T. Fukuda and T. Shibata, "Reserch Trends in Neuromorphic Control," Journal of Robotics and Mechatronics, Vol. 2-4, pp. 1-15, (1991)

34）藪田, 山田, “ニューラルネットによるロボットの力制御”, 日本ロボット学会誌, Vol. 9-2, pp. 224-231 (1991)

35）橋本他，“ニューラルネットによる最適制御の自己組織化 ーブランコ漕ぎロボットの学習制御一”, ロボ・メカ’ 91 講 演論文集, pp. 351-354 (1991)

36）福田他, “神経回路モデルによるロボット・マニピュレー夕 の位置・力制御の研究 (第 2 報)”, 機論, C 編, Vol. 57-535, pp. 866-873 (1991)

37）福田他, “神経回路モデルによるロボット・マニピュレータ の位置・力制御の研究 (第 3 報)”, 機論, C 編, Vol. 57-535, pp. 874-881 (1991)

38）柴田他, “神経回路モデルによるロボット・マニピュレー夕 の位置・力制御の研究 (第 4 報)”, 機論, C 編, Vol. 57-539, pp. 2305-2312 (1991)

39) M. I. Jordan, "Supervised Learning and System with Excess Degree of Freedom," COINS technical Report, Vol. 88-27, pp. 1-41 (1988)

40）福田, 柴田, “ニューラルネットワークを用いた位置・カの 適応制御”, 日本ロボット学会誌, Vol. 6-6, pp. 778-783 (1991)

41) T. Fukuda et al., "Neuromorphic Control for Robotic Manipulators, -Adaptation and Learning-," IEEE Trans. on Industrial Electronics, Vol. 39-6, pp. 497-503 (1992)

42）福田他, “センサ・インテグレーション・システムの研究(第 1 報)”, 機論, C 編, Vol.56-532, pp. 3300-3305 (1990)

43）福田他, “新規パターンを追加学習するための新しいニュ 一ロンモデル”，計測自動制御学会論文集, Vol. 29-3 (1993)

44) L. A. Zadeh, "Fuzzy Sets," Information and Control, Vol. 8, p. 228 (1965)

45）菅野, “ファジィ制御”, 日刊工業新聞社, p. 177 (1988)

46) E. H. Mamdani, "Applications of Fuzzy Algorithms for Control of Simple Dynamic Plant," Proc. of IEEE, Vol. 121-12, pp. 1585-1588 (1974)

47) T. Shibata and T. Fukuda, "Skill Based Control by Using Fuzzy Neural Network for Hierarchical Intelligent Control," Proc. of IJCNN'92-Baltimore, Vol.2, pp. 81-86 (1992)

48）林, 馬野, “ファジィ・ニューラルネットワークの現状と展 望”, 日本ファジィ学会誌, Vol. 5-2, pp. 178-190 (1993)

49）石川，“ファジィ制御を用いた自律型移動ロボットの誘導 方式の検討”, 日本ロボット学会誌, Vol. 9-2, pp. 149-161 (1991)

50）福田他，“遺伝アルゴリズムを用いたファジィモデルの学 習”, 電気学会論文誌, Vol. 113-C-7, pp. 495-501 (1993)

51) D. A. White and D. A. Sofge (Ed.), "Handbook of Intelligent Control-Neural, Fuzzy, and Adaptive 
Approaches", Van Nostrand Reinhold (1992)

52) M. A. Lee and H. Takagi, "Integrating Design Stage of Fuzzy Systems using Genetic Algorithms," Proc. of IEEE Int'l Conf. on Fuzzy Systems, pp. 612-617 (1993)

53) J. M.Keller et al., "Interpretation of Nodes in Networks for Fuzzy Logic," Proc. of IEEE Int'l Conf. on Fuzzy Systems, pp. 1203-1207 (1993)

54) C. L. Karr and E. J. Gentry, "Fuzzy Control of $\mathrm{pH}$ Using Genetic Algorithm," IEEE Trans. on Fuzzy Systems, Vol. 1-1, pp. 46-53 (1993)

55) D. E. Goldberg, "Genetic Algorithm in Search, Optimization, and Machine Learning," Addison. Wesley (1989)

56）柴田他, “Genetic Algorithm を用いた移動ロボットの最 適経路計画”, 機論, C 編, Vol. 58-553, pp. 1442-1449, (1992)

57）柴田, 福田, “Genetic Algorithmを用いた移動ロボット の最適経路計画 (第 2 報)”, 機論, C編, Vol. 59-560, pp. 1134-1141 (1993)

58）柴田, 福田, “マルチエージェントシステムの遺伝アルゴリ ズムを用いた学習による進化的協調行動”, 日本ロボット 学会, Vol. 11-8 pp. 1272-1280 (1993)

59) J. Koza, "Genetic Programming on the Programming of Computers by Means of Natural Selection," MIT Press (1992)

60) J. D. Schaffer et al., "Combinations of Genetic Algorithms and Neural Networks: A Survey of the State of the Art," Proc. of IEEE COGANN-92, pp. 1-37 (1992)

61) R.C. Eberhart, "The Role of Genetic Algorithm in Neural Network Query-Based Learning and Explanation Facilities," Proc. of IEEE COGANN-92, pp. 169-
183 (1992)

62）柴田, 福田,“ファジィ評価を用いた遺伝アルゴリズムによ るロボットの行動計画”, 計測自動制御学会論文集 (1993) (掲載予定)

63）植山他，“再構成可能自己組織化システムの研究(第 10 報)”, 機論, Vol. 58-549, pp. 1466-1473 (1992)

64) C. G. Langton (Ed.), "Artificial Life,” Addison Wesley (1989)

65) C. G. Langton et al., (Ed.), "Artificial Life II," Addison Wesley (1992)

66）田野他, “多足步行機械の学習による歩容獲得”，第 10 回 日本ロボット学会学術講演会予稿集, pp. 1129-1132 (1992)

67) J. J. Grefenstette, "The Evolution of Strategies for Multiagent Environments," Adaptive Behavior, Vol. 11, pp. 65-90 (1992)

68) R. D. Beer, "Evolving Dynamical Neural Networks for Adaptive Behavior," Adaptive Behavior, Vol.1-1, pp. 91-122 (1992)

69) J. A. Albus et al., "NASREM the NASA/NBS Standard Reference Model for Telerobot Control System Architecture," Proc. of the 20th ISIR, pp. 1-7 (1989)

70) A. Meystel, "Multiresolutional Recursive Design Operator for Intelligent Machines," Proc. of the IEEE Int'l Symp. on Intelligent Control, pp. 79-84 (1991)

71) 福田, 柴田, “インテリジェントシステムのためのニュー ロ・ファジィ・GA の統合・融合化技術の展望”, 機論, C 編, Vol. 59-564, pp. 2282-2289 (1993)

72) T. Shibata, "Hierarchical Intelligent Control of Robotic Motion," Ph.d Dissertaiton, Nagoya University (1992)

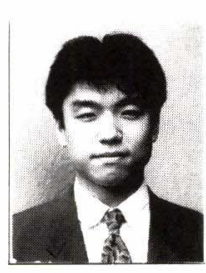

\section{柴田崇徳}

(Takanori SHIBATA)

1967 年 2 月 10 日生. 1992 年名古屋大学 大学院電子機械工学専攻博士課程修了. 工 学博士. 日本学術振興会特別研究員, 名古 屋大学工学部機械情報システム工学科助手 を経て, 1993 年より通産省工業技術院機械 技術研究所ロボット工学部バイオロボティクス課研究員. IEEE, JSME, SICE, SOFT 他の会員.

(日本ロボット学会正会員)

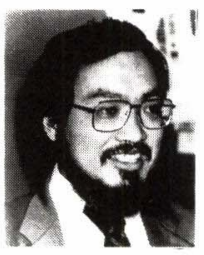

福田敏男 (Toshio FUKUDA)

1948 年 12 月 12 日生. 1971 年早稲田大学 理工学部機械工学科卒業. 1977 年東京大学 大学院博士課程修了, 工学博士。通産省工 業技術院機械技術研究所研究官, 及び東京 理科大学工学部機械工学科助教授を経て, 1989 年 4 月より名古屋大学工学部機械情報 システム工学科教授. IEEE IES Vice President, IEEE NNC Secretary, IEEE R \& A TC 委員長等歴任.

(日本ロボット学会正会員) 